\title{
Erratum to: Oxygen in Molten Iron: Deoxidation with Silicon and Aluminum
}

\author{
J.W. MATOUSEK ${ }^{1,2}$ \\ 1.-Englewood, CO 80111-5415, USA. 2.-e-mail: jwmatousek@q.com
}

For more than 80 years, the subject of oxygen in molten steel and its removal by various agents has attracted the attention of practical and theoretical metallurgists. This review summarizes some historical data for oxygen contents of steels and some basic thermodynamics for its dissolution and elimination, primarily by the deoxidizers silicon and aluminum.

\section{INTRODUCTION}

Some of the agents used to deoxidize steel, as summarized in The Making Shaping and Treating of Steel (MSTS), ${ }^{1}$ are given in Table I, with the oxygen contents in parts per million, ppm. Zhang and Thomas ${ }^{2}$ reported the standards in Table II for current mill-steel products.

These low levels of oxygen are achieved with "cored wire," which is control fed from spools into the melt in ladle refining furnaces. The "wire" is $13 \mathrm{~mm}$ diameter, low-carbon steel tubing packed with the following agents (among others): CaAlFe, $\mathrm{FeTi}, \mathrm{CaSi}, \mathrm{CaAl}, \mathrm{CaFe}$, and C. Calcium oxidizes to $\mathrm{CaO}$ and promotes the fixing of the deoxidation products in the slag to minimize nozzle blockages during casting.

To put these analyses in historical perspective, the compositions of a set of standard bars of Bessemer converter and open-hearth furnace steels from 1937 are given in Table III. These were collected and analyzed in a cooperative study to compare methods for determining the oxygen contents of steels. ${ }^{3,4}$ Note that the writing of all analyses to four decimal places does not imply a degree of accuracy. They are presented in this form so that by ignoring the decimal point the compositions are given in $\mathrm{ppm}$.
The original publication of this article included errors introduced during the production process. The errors are corrected herein.

The online version of the original article can be found under doi:10.1007/ s11837-015-1325-8.

\section{OXYGEN IN IRON}

The serious study of oxygen behavior in molten iron began more than 80 years ago. Two of the early investigations stand out: Dastur and Chipman ${ }^{5}$ and Floridis and Chipman. ${ }^{6}$ Both studies measured the oxygen content of iron as a function of the $\mathrm{H}_{2} \mathrm{O} / \mathrm{H}_{2}$ ratio of partial pressures, as in Eq. 1. Dastur and Chipman took the equilibrium constant to be of the form given in Eq. 2. Floridis and Chipman added the activity coefficient in Eq. 3.

$$
\begin{gathered}
\mathrm{H}_{2} \mathrm{O}(\mathrm{g})=\mathrm{H}_{2}(\mathrm{~g})+[\mathrm{O}]_{\mathrm{Fe}} \\
K_{2}=\left(\mathrm{H}_{2} / \mathrm{H}_{2} \mathrm{O}\right) *[\mathrm{O}]_{\mathrm{w} / \mathrm{o}} \\
K_{3}=\left(\mathrm{H}_{2} / \mathrm{H}_{2} \mathrm{O}\right) * f_{\mathrm{O}}[\mathrm{O}]_{\mathrm{w} / \mathrm{o}}
\end{gathered}
$$

The following notation will be used throughout this analysis: $\left(\mathrm{H}_{2} / \mathrm{H}_{2} \mathrm{O}\right)$ represents the ratio of partial pressures, $[\mathrm{O}]_{\mathrm{w} / \mathrm{o}}$ is the oxygen content of iron given in weight percent (w/o), $f_{\mathrm{O}}$ is the Henrian activity coefficient, $[\mathrm{O}]_{x}$ is the Raoultian mole fraction of oxygen in iron, and $\gamma^{\circ}$ is the corresponding Henrian activity coefficient. In solutions of less than $1000 \mathrm{ppm}[\mathrm{O}]$ and taking the molecular weight of oxygen to be 16 and iron to be 56 , the following simplifications can be made: $[\mathrm{O}]_{x}=[\mathrm{O}]_{\mathrm{w} / \mathrm{o}} /$ $28.6=[\mathrm{O}]_{\mathrm{ppm}} / 28.6 \mathrm{E} 4 ; \quad K_{\mathrm{w} / \mathrm{o}}=28.6 / \gamma^{\circ}=1 / f_{\mathrm{O}} ; \quad$ and $[\mathrm{O}]_{a / 0}($ atomic percent $)=[\mathrm{O}]_{x} * 100$. All activities are taken to be equal to $\sqrt{ } p \mathrm{O}_{2}$ at the composition of interest; this is equivalent to taking the standard state for oxygen to be one bar pressure. An alter- 
native to this approach is considered below. The relationship between these quantities in dilute solutions is shown in Fig. 1.

The experimental data of Dastur and Chipman are shown in Fig. 2; the equation for the regression line is given by Eq. 4 (from the "Second Law Method"), with 10 data points taken at $1563^{\circ} \mathrm{C}$.

$$
\begin{gathered}
\mathrm{H}_{2}+[\mathrm{O}]=\mathrm{H}_{2} \mathrm{O} \\
K_{4}=\left(\mathrm{H}_{2} \mathrm{O} / \mathrm{H}_{2}\right) /[\mathrm{O}]_{\mathrm{w} / \mathrm{o}} ; \log K_{4}=-7084 / T+3.19
\end{gathered}
$$

\begin{tabular}{|c|c|c|}
\hline Classification & Deoxidizing agent & {$[0]$, ppm } \\
\hline Deoxidized & $\mathrm{Fe} / \mathrm{Mn}$ & $100-200$ \\
\hline \multirow[t]{3}{*}{ Semikilled } & $\mathrm{Si} / \mathrm{Mn}$ & $50-70$ \\
\hline & $\mathrm{Si} / \mathrm{Mn} / \mathrm{Al}$ & $25-40$ \\
\hline & $\mathrm{Si} / \mathrm{Mn} / \mathrm{Ca}$ & $15-20$ \\
\hline Killed & $\mathrm{Al}$ & $2-4$ \\
\hline
\end{tabular}

Table I. Oxygen contents of deoxidized steel ${ }^{1}$
The equation for the equilibrium constant for the reaction $\quad \mathrm{H}_{2}+1 / 2 \quad \mathrm{O}_{2}=\mathrm{H}_{2} \mathrm{O} \quad(\log \quad K=13,089 /$ $T-3.00)^{8}$ was combined with Eq. 4 a to yield Eq. 5a; $\log K_{5 \mathrm{~b}}$ was derived taking only one data point at $1563^{\circ} \mathrm{C}$.

$$
1 / 2 \mathrm{O}_{2}=[\mathrm{O}] ; K=[\mathrm{O}]_{\mathrm{w} / \mathrm{o}} / \sqrt{ } p \mathrm{O}_{2}
$$

$$
\log K_{5 \mathrm{a}}=6005 / T+0.19
$$

$$
\log K_{5 \mathrm{~b}}=6184 / T+0.10
$$

This relationship in $M S T S^{1}$ is given by Eq. 6 .

$$
\log K_{6}=6046 / T+0.242
$$

The experimental results from Floridis and Chipman are shown in Fig. 3. The slopes of the two

\begin{tabular}{|c|c|c|c|}
\hline Steel product & {$[\mathrm{C}](\mathbf{p p m})$} & {$[\mathbf{N}](\mathbf{p p m})$} & {$[0](\mathbf{p p m})^{\mathbf{a}}$} \\
\hline Interstitial free $\mathrm{e}^{\mathrm{b}}$ & 30 & 40 & 40 \\
\hline Interstitial free & 10 & 50 & $30^{\mathrm{c}}$ \\
\hline Automotive and deep drawing & 30 & 30 & 20 \\
\hline Drawn and ironed cans & 30 & 30 & $20^{\mathrm{c}}$ \\
\hline Alloy bars & & $10-20$ & 10 \\
\hline Line pipe & & & 30 \\
\hline Ball bearings & & 40 & 10 \\
\hline Tire cord & & $30-40$ & 15 \\
\hline Heavy plate & & 60 & 20 \\
\hline Wire & & & 30 \\
\hline
\end{tabular}
lines give values of $K_{7}$ (Eq. 7), and the equation for $\log K$ is again derived by the Second Law Method.

$$
\log K_{7}=5048 / T+0.736
$$

\begin{tabular}{|c|c|c|c|c|c|}
\hline Type of steel & $\%[\mathbf{C}]$ & $\%[\mathrm{Si}]$ & $\%[\mathrm{Mn}]$ & $\%[\mathrm{Al}]$ & $\%[0]$ \\
\hline Low carbon, rimming & 0.0300 & 0.0020 & 0.3100 & 0.0011 & 0.0180 \\
\hline Medium carbon, high-Mn, Si-killed & 0.4200 & 0.2600 & 1.1500 & 0.0011 & 0.0170 \\
\hline Bessemer, semikilled & 0.1200 & 0.0240 & 0.7200 & 0.0011 & 0.0170 \\
\hline Special, low carbon, Al killed & 0.1700 & 0.0900 & 0.6500 & 0.0032 & 0.0020 \\
\hline Low carbon, Si killed & 0.2200 & 0.1400 & 0.4500 & 0.0011 & 0.0090 \\
\hline Medium carbon, Si killed & 0.4300 & 0.2000 & 0.4700 & 0.0011 & 0.0070 \\
\hline Open-hearth iron, rimming & 0.0160 & 0.0010 & 0.0240 & 0.0011 & 0.1060 \\
\hline Low carbon, higher in oxygen & 0.2000 & 0.0300 & 0.4500 & 0.0159 & 0.0170 \\
\hline
\end{tabular}

Table II. Steel quality requirements ${ }^{2}$

${ }^{a}$ Total as free oxygen and oxide inclusions.

${ }^{\mathrm{b}}$ Interstitial elements-generally H, B, C, and N.

cEstimated by the author.

Table III. Analyses of miscellaneous steels ${ }^{3,4}$ 


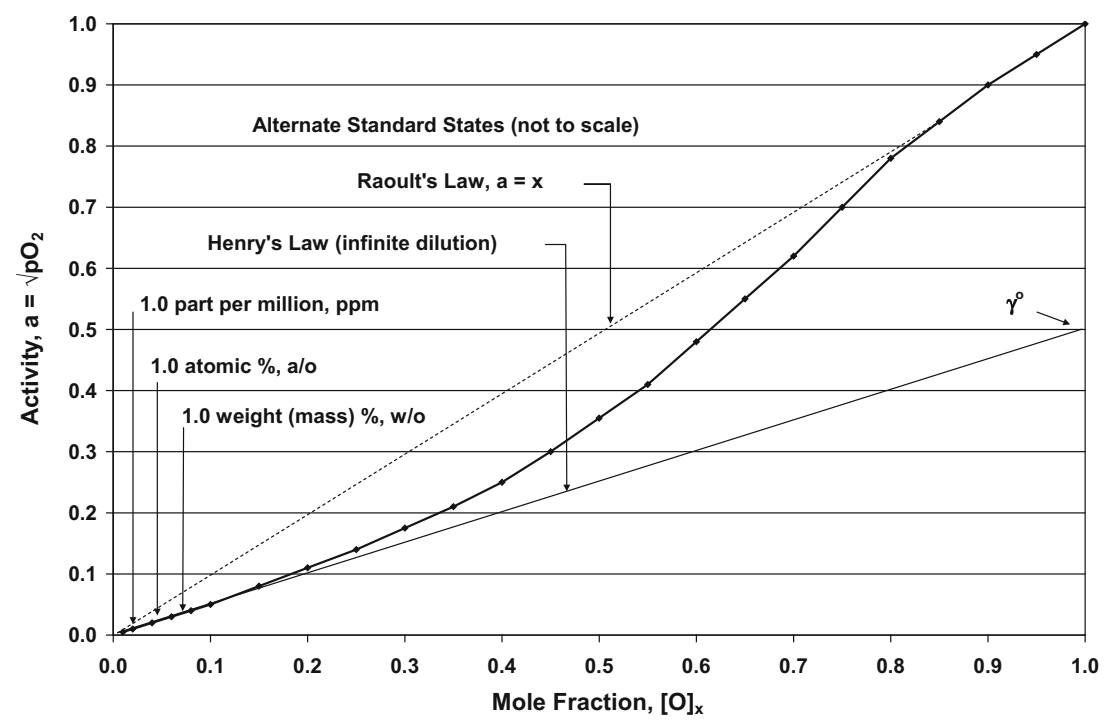

Fig. 1. Alternative standard states for dilute solutions.

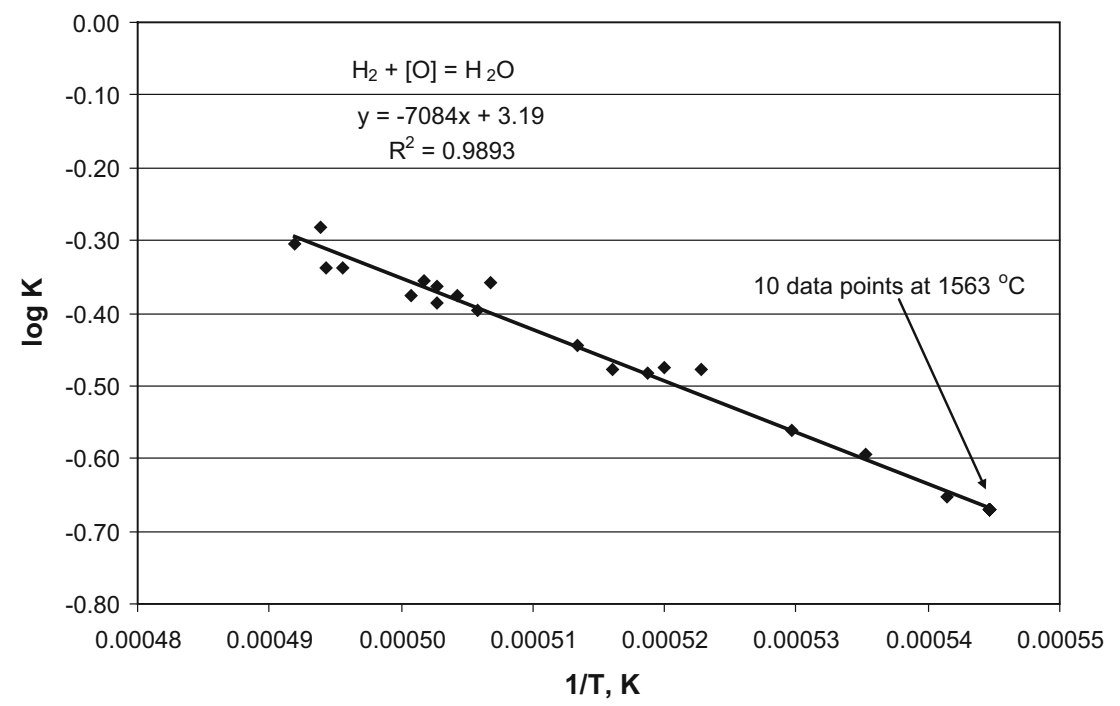

Fig. 2. The equilibrium of oxygen in iron under atmospheres of $\mathrm{H}_{2}$ and $\mathrm{H}_{2} \mathrm{O}^{5}$

Floridis and Chipman, analyzing their own data and those of others (including Dastur and Chipman), derived the equivalent of Eq. 8, and from it they proposed the activity coefficient of oxygen to be given by Eq. 9 . The term $e_{i}^{j}\left(\right.$ as in $\left.\log f=e[\mathrm{O}]_{\mathrm{w} / \mathrm{o}}\right)$ is named the "interaction coefficient"; the subscript refers to oxygen and the superscript to the added element, including oxygen itself. This topic is considered again in more detail below.

$$
\begin{gathered}
K_{8}=f_{\mathrm{O}}[\mathrm{O}]_{\mathrm{w} / \mathrm{o}} / \sqrt{ } p \mathrm{O}_{2} ; \log K_{8}=6039 / T+0.200 \\
\log f_{\mathrm{O}}=-0.2[\mathrm{O}]_{\mathrm{w} / \mathrm{o}}=e_{\mathrm{O}}^{\mathrm{O}}[\mathrm{O}]_{\mathrm{w} / \mathrm{o}}
\end{gathered}
$$

Tankins, Gokcen, and Belton ${ }^{9}$ gave this expression as Eq. 10 and concluded that the value of $e^{\mathrm{O}}$ is essentially zero.

$$
\log K_{10}=6272 / T+0.13
$$

At $1600^{\circ} \mathrm{C}$, the values of $\log K$ from the above equations are: $\log K_{5 \mathrm{a}}=3.40, \log K_{5 \mathrm{~b}}=3.40, \log$ $K_{6}=3.47, \quad \log K_{7}=3.43, \quad \log K_{8}=3.42, \quad$ and $K_{10}=3.48$.

It is important to note at this point that the minimum oxygen level investigated in the Chipman and Tankins studies was approximately $200 \mathrm{ppm}$, greater than the semikilled steels of Table I and all 


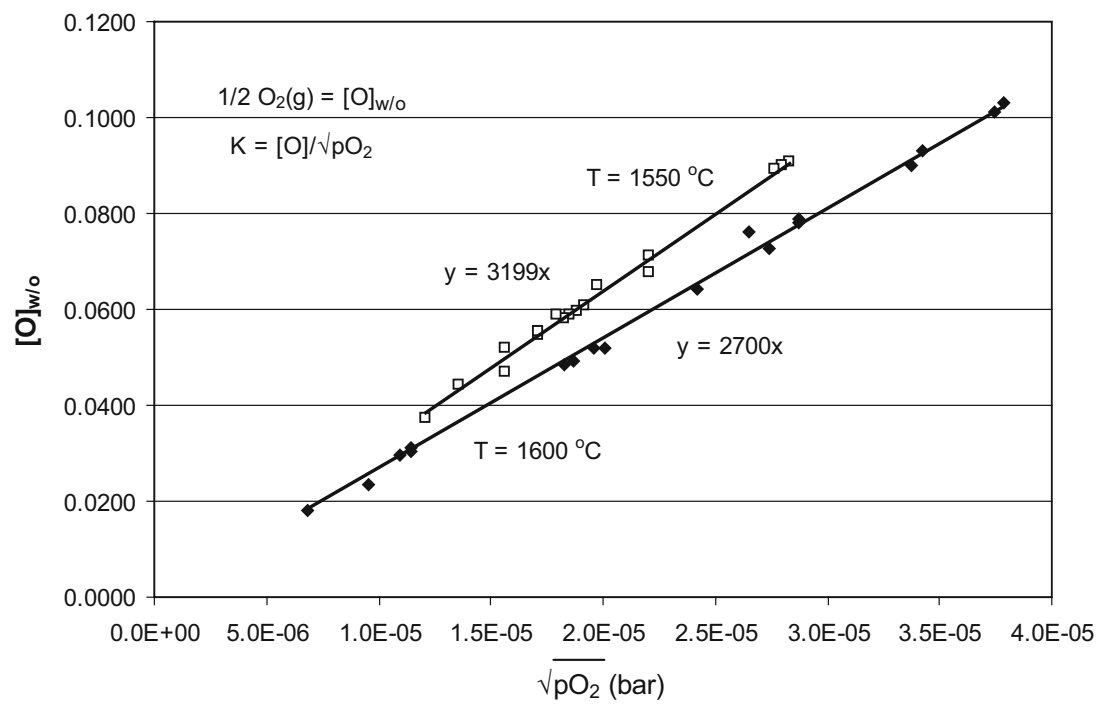

Fig. 3. Oxygen activities and concentrations in molten iron. ${ }^{6}$

of the steels in Table II. In an ideal world of dilute solutions, below $[\mathrm{O}]_{x}=0.15$ in Fig. 1 , all of the activities would fall on the Henry's Law line and therefore be directly proportional to the concentration. For nearly 80 years, this assumption has been made regarding the extrapolation of curves for activity and concentration of oxygen in iron such as in Fig. 3. It has been taken that the data collected over the range 200 to $2000 \mathrm{ppm}$ [O] could be extrapolated in a linear fashion down to zero oxygen content. However, there is no direct experimental evidence to support this conclusion for the behavior of oxygen in pure iron at low concentrations. It seemed appropriate to examine some deoxidized steels to look for answers.

Fruehan, Martonik, and Turkdogan, ${ }^{10}$ using solid-electrolyte oxygen sensors, studied oxygen in iron-both pure and that deoxidized with silicon, aluminum, and vanadium. The cell is diagramed in Eq. 11; it is written to emphasize the thermocouple voltage between the $\mathrm{Pt}^{+}$and $\mathrm{Mo}^{++}$electrodes and the oxygen cell voltage between $\mathrm{Mo}^{++}$and $\mathrm{Mo}^{-}{ }^{11}$ Zirconia electrolytes show electronic conduction at low oxygen pressures, so in some experiments with aluminum reduction, $\mathrm{ThO}_{2}$ cells were substituted. The cell electromotive force (emf), after correction for the thermocouple effect, is given by the Nernst equation (Eq. 12).

$$
\mathrm{Pt}\left(\mathrm{Rh}_{10}\right)^{+}-\mathrm{Mo}^{++}, \mathrm{Cr} / \mathrm{Cr}_{2} \mathrm{O}_{3} / / \mathrm{ZrO}_{2} / /[\mathrm{O}]_{\mathrm{Fe}}, \mathrm{Mo}^{-}
$$

$$
\begin{aligned}
E & =-R T / z F \log \left[p\left(\mathrm{O}_{2}\right)_{\mathrm{Fe}} / p\left(\mathrm{O}_{2}\right)_{\mathrm{ref}}\right] \\
& =E^{\mathrm{o}}-R T / z F \log p\left(\mathrm{O}_{2}\right)_{\mathrm{Fe}}
\end{aligned}
$$

$E$ is the cell emf in millivolts $(\mathrm{mV})$, with the original voltage signs reversed to conform to recent usage. ${ }^{11} R$ is the gas constant, $19.14 \mathrm{~J} / \mathrm{mol} \mathrm{K}$, written for $\log p\left(\mathrm{O}_{2}\right) ; T$ is the absolute temperature; $z$ is the charge transfer (four in the case of $\mathrm{O}_{2}$ ); $F$ is the Faraday constant, $96.5 \mathrm{~J} / \mathrm{mV} \mathrm{mol} ; \log p\left(\mathrm{O}_{2}\right)$ is the base-ten logarithm of the oxygen pressure in bars; and $E^{\circ}$ is the standard electrode potential for the $\mathrm{Cr} /$ $\mathrm{Cr}_{2} \mathrm{O}_{3}$ reference electrode, calculated from the relationship $\Delta G^{\circ}=-z F E^{\circ}$ for the reaction $2 / 3$ $\mathrm{Cr}_{2} \mathrm{O}_{3}=4 / 3 \mathrm{Cr}+\mathrm{O}_{2}(\mathrm{~g})$ and $\Delta G^{\circ}=749.0-0.169 T$, $\mathrm{kJ} / \mathrm{mol} \mathrm{O}$.

The results are shown in Fig. 4; the regression line was drawn for just the Fe-O experiments. Including all the data changes the slope only a little because the points are weighted to the right and the line is drawn though the origin. The slope of the line is 2490 , equal to $K_{\mathrm{w} / \mathrm{o}}$, and from it the following are calculated: $f_{\mathrm{O}}=1 / K_{\mathrm{w} / \mathrm{o}}=4.0 \mathrm{E}-4 ; \gamma^{\circ}=28.6 \times f_{\mathrm{O}}=$ 0.0114 . The value of $K$ agrees with those calculated above, so again it might be concluded that a Henry's Law line can be drawn down to zero oxygen content. To test this hypothesis, a closer look at the experiments with silicon and aluminum deoxidized steels must be taken. But first, it is necessary to make a critical assumption: namely that the chemical activity of oxygen in deoxidized steel is the same as that of oxygen in pure iron at the same concentration. For this to be true, it must be known that the oxygen analyzed in the metal is free oxygen, not oxygen in the form of solid inclusions of $\mathrm{SiO}_{2}$ or $\mathrm{Al}_{2} \mathrm{O}_{3}$. Iyengar and Duderstadt ${ }^{12}$ (with reference to work by Miyashita ${ }^{13}$ ) noted that in deoxidation with silicon, the precipitation of silica is complete after $60 \mathrm{~s}$, and the silica separates from the melt within 8-12 min, leaving behind only 


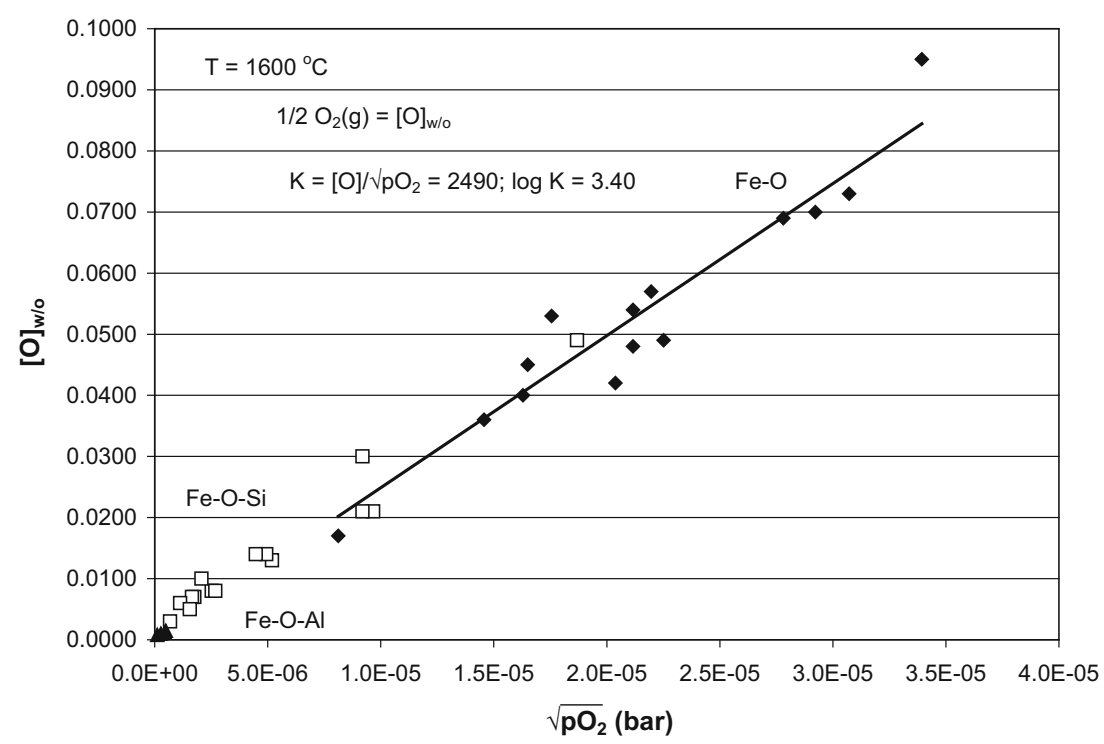

Fig. 4. Oxygen pressures and concentrations in molten iron at $1600^{\circ} \mathrm{C}^{9}$

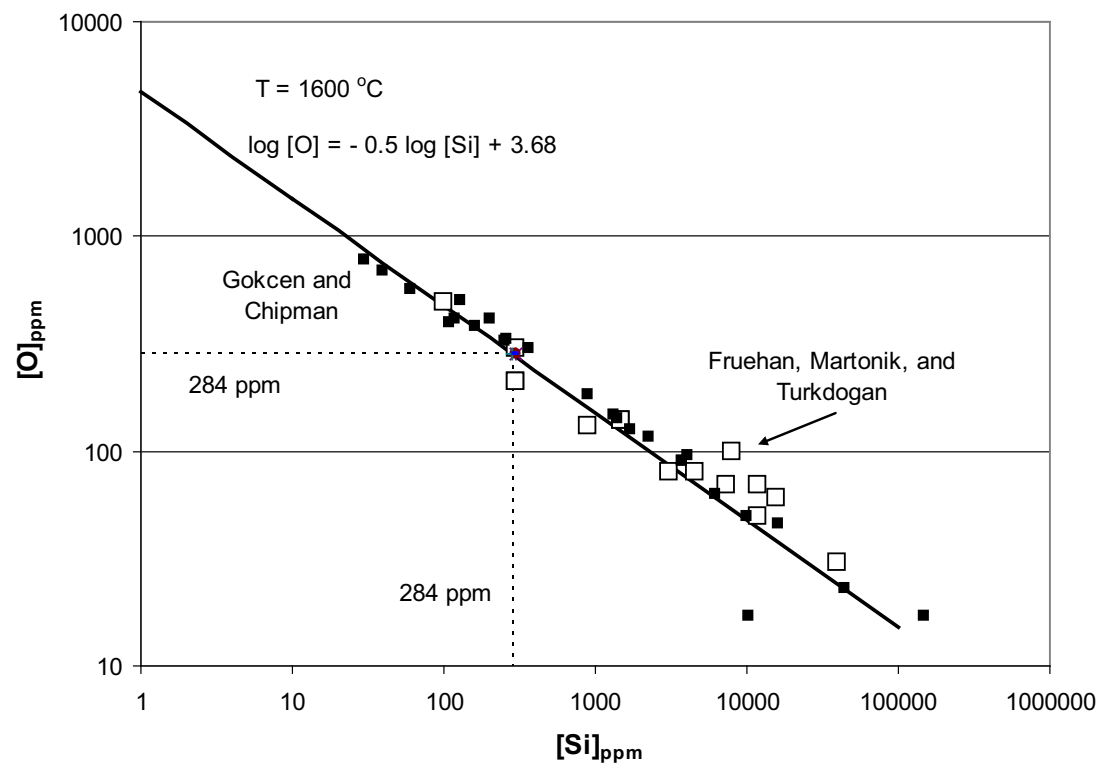

Fig. 5. Deoxidation of iron with silicon.

dissolved oxygen in equilibrium with dissolved silicon, and thus free to generate a true emf in the oxygen sensor. It is assumed that the data from Fruehan and co-workers meet these criteria. The agreement of the value of $K$ in Fig. 4 with those previously calculated supports this conclusion.

The effect of the interaction coefficient on the activity coefficient of oxygen was mentioned above in association with Eq. 9. For a combination of deoxidizing agents, Eq. 13 applies. The published values for the coefficients are: $e_{\mathrm{O}}^{\mathrm{O}}=-0.20, e_{\mathrm{O}}^{\mathrm{Si}}=$ -0.131 , and $e_{\mathrm{O}}^{\mathrm{Al}}=-3.9 .^{1}$

$$
\log f_{\mathrm{O}}=e_{\mathrm{O}}^{\mathrm{O}}[\mathrm{O}]_{\mathrm{w} / \mathrm{o}}+e_{\mathrm{O}}^{\mathrm{Si}}[\mathrm{Si}]_{\mathrm{w} / \mathrm{o}}+e_{\mathrm{O}}^{\mathrm{Al}}[\mathrm{Al}]_{\mathrm{w} / \mathrm{o}}
$$

But if $f_{\mathrm{O}}$ is a constant, as it appears to be in Fig. 3 (at $1600^{\circ} \mathrm{C}, \quad f_{\mathrm{O}}=1 / 2700=3.7 \mathrm{E}-4$ ) and Fig. 4 $\left(f_{\mathrm{O}}=1 / 2490=4.0 \mathrm{E}-4\right)$, then the values of $e_{i}^{j}$ must be zero. Further analysis using interaction coefficients with these data was inconclusive, and no more consideration was given to this approach.

\section{DEOXIDATION OF IRON WITH SILICON}

Figure 5 plots the experimental data of Fruehan, Martonik, and Turkdogan for the deoxidation of iron with silicon as the open squares. The solid squares and regression line are from Gokcen and Chipman; ${ }^{14}$ their $\log K$ is given by Eq. 14 a. $M S T S^{1}$ gives this equation as Eq. 14b. The light, broken 


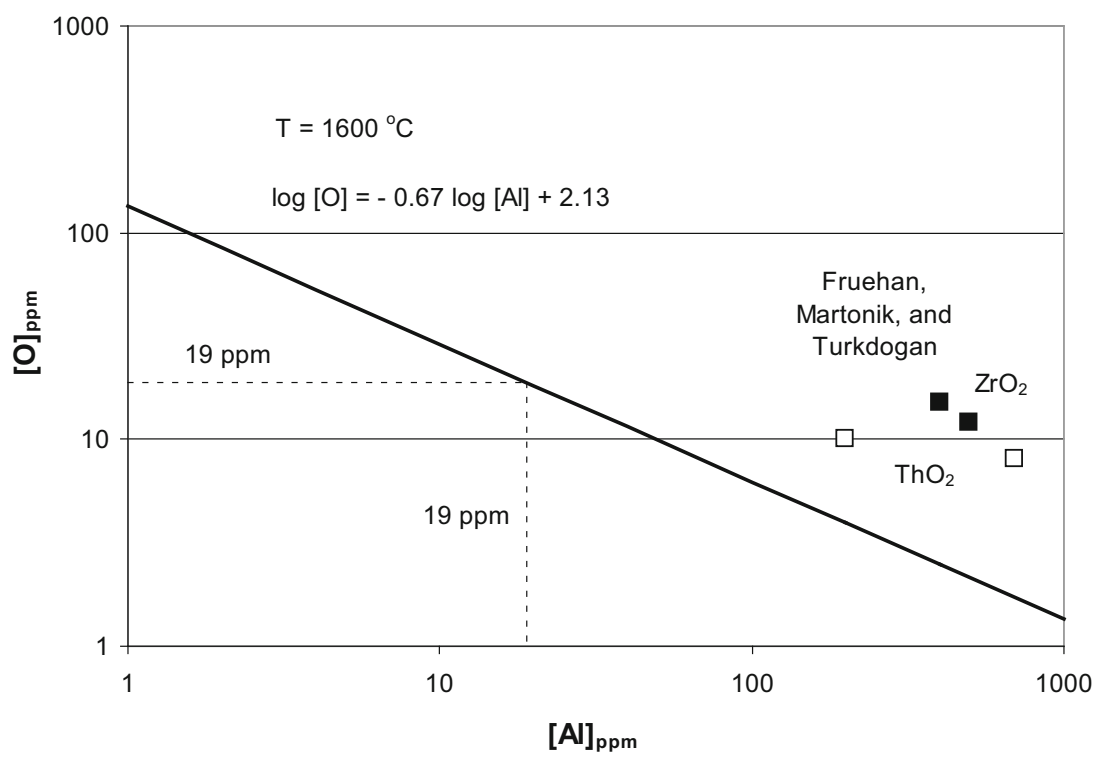

Fig. 6. Deoxidation of iron with aluminum.

Table IV. Standard states for oxygen in iron at $1600^{\circ} \mathrm{C}$

\begin{tabular}{|c|c|c|c|c|c|}
\hline Standard state & $\underline{1.0[0]_{x}}$ & $\underline{1.0[0]_{\mathrm{w} / \mathrm{o}}}$ & $\underline{1.0[0]_{\mathbf{a} / \mathbf{o}}}$ & $\underline{2290[O]_{\text {ppm }}}$ & $\underline{1.0[0]_{\text {ppm }}}$ \\
\hline $\begin{array}{l}\log p\left(\mathrm{O}_{2}\right)^{\circ} \\
\sqrt{p} \mathrm{O}_{2}(\mathrm{bar})\end{array}$ & $\begin{array}{c}-3.93 \\
1.09 \mathrm{E}-2\end{array}$ & $\begin{array}{c}-6.84 \\
3.80 \mathrm{E}-4\end{array}$ & $\begin{array}{c}-7.93 \\
1.09 \mathrm{E}-4\end{array}$ & $\begin{array}{c}-8.12 \\
8.70 \mathrm{E}-5\end{array}$ & $\begin{array}{c}-14.84 \\
3.80 \mathrm{E}-8\end{array}$ \\
\hline
\end{tabular}

lines define a set of conditions that satisfy the equilibrium, $K_{\mathrm{w} / \mathrm{o}}=(0.0284) .^{3}$ There is apparent deviation in the Fruehan data from that of Gokcen at oxygen concentrations below $100 \mathrm{ppm}$, but the scatter is too great to permit any concrete conclusions to be drawn.

$$
\begin{gathered}
{[\mathrm{Si}]_{\mathrm{w} / \mathrm{o}}+2[\mathrm{O}]_{\mathrm{w} / \mathrm{o}}=\mathrm{SiO}_{2}} \\
\log K_{14 \mathrm{a}}=-32,000 / T+12.29 \\
\log K_{14 \mathrm{~b}}=-30,410 / T+11.59
\end{gathered}
$$

Once again, the agreement of the Fruehan data with that from the dedicated studies of deoxidation with silicon suggest that the oxygen sensor and the chemical analysis are both seeing only free oxygen. That is, there is no significant amount of oxygen present in the melt as solid inclusions.

\section{DEOXIDATION OF IRON WITH ALUMINUM}

Figure 6 plots the experimental data of Fruehan, Martonik, and Turkdogan for the deoxidation of iron with aluminum. The line is from $M S T S,{ }^{1}$ given by Eq. 15a. The theoretical line indicates that iron should be deoxidized to $10 \mathrm{ppm}$ with an equilibrium aluminum content of $50 \mathrm{ppm}$. The Fruehan data suggest that approximately $400-500 \mathrm{ppm}$ is required. This conclusion is qualitatively confirmed by Ghorpade, Heine, and Gilliland, ${ }^{15}$ who observed similar behavior in an industrial setting. They suggest that the discrepancy is the effect of kinetics, not thermodynamics, but also that aluminum may enhance the effectiveness of silicon.

Equation $15 \mathrm{a}$ gives $K$ at $1600^{\circ} \mathrm{C}$ to be $2.4 \mathrm{E}-14=(0.0019){ }^{5}$ The value of $K$ calculated from $450 \mathrm{ppm}$ [Al] and $10 \mathrm{ppm}$ [O] is $2.0 \mathrm{E}-12$, which suggests that the driving force of deoxidation with aluminum in the practical world is less than theoretical analysis would predict. Fitterer ${ }^{16}$ proposed that in commercial practice, $\log K$ should be represented by Eq. 15b: At $1600^{\circ} \mathrm{C}$, log $K_{15 b}=-9.0$; $450 \mathrm{ppm}[\mathrm{Al}]$ corresponds to $80 \mathrm{ppm}$ [O].

$$
\begin{gathered}
2[\mathrm{Al}]_{\mathrm{w} / \mathrm{o}}+3[\mathrm{O}]_{\mathrm{w} / \mathrm{o}}=\mathrm{Al}_{2} \mathrm{O}_{3} \\
\log K_{15 \mathrm{a}}=-62,680 / T+19.85 \\
\log K_{15 \mathrm{~b}}=-50,571 / T+18.0
\end{gathered}
$$




\section{CONCLUSION}

All of the oxygen activities above were taken to be equal to the square root of the oxygen partial pressure in bars, and standard concentrations were taken to be in weight percent. Another approach is to take the activity to be equal to the square root of the pressure at the concentration of interest divided by the square root of the pressure at the standard state. Then, $a_{\mathrm{O}}=\sqrt{ } p \mathrm{O}_{2} / \sqrt{ } p^{\circ} \mathrm{O}_{2}=1.0$ at the standard state. Concentrations in $[\mathrm{O}]_{\mathrm{w} / \mathrm{o}}$ and pressure in bars are convenient units in thermodynamic calculations as they keep the numbers from becoming unwieldy. For example, with a standard state of $[\mathrm{O}]_{\mathrm{w} / \mathrm{o}}$, the value of $K=2630$; this becomes $26.3 \mathrm{E} 6$ on the $[\mathrm{O}]_{\text {ppm }}$ scale. A parts-per-million standard state is more useful in general discussions and on the shop floor. If Henry's Law applies, then activities are given directly in ppm oxygen; this is a common feature of commercial oxygen sensors. At $1600^{\circ} \mathrm{C}$, iron is saturated with oxygen at $2290 \mathrm{ppm}$. This condition has not been taken as the standard state in any known studies, but it may offer an advantage in special cases. Some properties of these and other standard states are summarized in Table IV; all assume that Henry's Law applies at these low concentrations.

In the more than 80 years that oxygen in iron has been studied, no concentrated effort has been made to define the thermodynamics of the simple system $\mathrm{Fe}-\mathrm{O}$ below $200 \mathrm{ppm}$ [O]. A leap of faith has been taken in the current analysis in assuming that the oxygen in equilibrium with pure iron containing $25 \mathrm{ppm}[\mathrm{O}]$ has the same activity as $25 \mathrm{ppm}[\mathrm{O}]$ in iron that has been deoxidized with silicon or aluminum. A dedicated study to determine the thermodynamic properties of oxygen in pure iron in the region 0 to $200 \mathrm{ppm}$ would be most welcome.

\section{REFERENCES}

1. R.J. Fruehan, editor, The Making, Shaping, and Treating of Steel (MSTS), Steelmaking and Refining, 11th ed. (Pittsburgh, PA: AISE Foundation, 1998).

2. L. Zhang and B.G. Thomas, ISIJ Int. 43, 271 (2003),

3. J.G. Thompson and V.C.F. Holm, J. Res. Natl. Bur. Stand. (U. S.), RP1114 21, 79 (1938).

4. S.L. Hoyt and M.A. Scheil, AIME Trans. 125, 313 (1937).

5. M.N. Dastur and J. Chipman, Metals Trans. 185, 441 (1949).

6. T.P. Floridis and J. Chipman, Trans. Met. Soc. AIME 212, 549 (1958).

7. M.W. Chase and C.A. Davis, editors, JANAF Thermochemical Tables, 3rd ed. (New York: American Chemical Society, 1986), pp. 14-15.

8. R.A. Robie and B.S. Hemingway, Thermodynamic Properties of Minerals and Related Substances, Bulletin 2131 (Washington, DC: U.S. Geological Survey, 1995).

9. E.S. Tankins, N.A. Gokcen, and G.R. Belton, Trans. Met. Soc. AIME 230, 820 (1964).

10. R.J. Fruehan, L.J. Martonik, and E.T. Turkdogan, Trans. Met. Soc. AIME 245, 1501 (1969).

11. J.W. Matousek, JOM 66, 1670 (2014).

12. R.K. Iyengar and G.C. Duderstadt, Trans. Met. Soc. AIME 246, 807 (1969).

13. Y. Miyashita, Trans. Iron Steel Inst. Japan 7, 1 (1967).

14. N.A. Gokcen and J. Chipman, Trans. AIME 194, 171 (1952).

15. S.C. Ghorpade, R.W. Heine, and R.G. Gilland, Elect. Fce. Proceedings (New York: ISS, American Institute of Mining, Metallurgical and Petroleum Engineers, 1975), pp. 108-115.

16. G.R. Fitterer, Open Hearth and Basic Oxygen Steelmaking Conference Proceedings, Vol. 59 (New York: ISS, American Institute of Mining, Metallurgical and Petroleum Engineers, 1976), pp. 212-216. 